THURSDAY, OCTOBER 4, I9I7.

\section{THE NEW EDUCATION BILL.}

I $F$ there has been any good fruit arising out of all the dreadful evil of the present colossal struggle, it may surely be found in the awakened interest which all classes of the English nation are taking in the question of education.

The events of the war have clearly demonstrated the advantage which accrues to a trained and well-instructed people not merely in the hideous business of war, but also from the point of view of industry and commerce, concerning which it is now freely admitted that our chief competitor, Germany, was already bidding fair to become our most successful rival (in the applications of chemical science she had already surpassed us), even in industries in which we at one time thought we could never be equalled, still less surpassed. So penetrating was the conviction that, by a happy inspiration, it led the Prime Minister to call for the services of a man who, by training, education, experience, and a proved sympathy with education in its widest aspects and its most pervasive forms, would bring to the office of President of the Board of Education a new vision and the enthusiasm which would rouse Parliament and the nation to a due sense of their responsibilities for the effective education of all classes of the people. So we have now as the incumbent of this high and responsible office, not a politician, not a mere seeker after the spoils of office, or one who regards the position as a stepping-stone to more considerable posts, but the Vice-Chancellor of the University of Sheffield, Mr. H. A. L. Fisher. So great is the impression which has already been made in the few months since he entered upon his new duties, as a result of the zeal and intelligence with which he has gripped the problems awaiting solution, that the conviction is growing that such an office ought never again to be the sport of party politics, but should be regarded as one which can be adequately filled and have its full effect only when placed in the hands of a trained mind, experienced in the problems of education and full of sympathy with its varied expression.

Already Mr. Fisher, on the introduction of the Education Estimates during last session, has made clear the importance of education and of the necessity that the teacher shall not only enjoy a better status, but also be more liberally remunerated, and he has induced Parliament to grant him a larger subvention for this purpose than has ever been known in the history of the Board of Education.
He has, moreover, signified his intention to ask Parliament to assent to a scheme of pensions for secondary- and technical-school teachers. On August $1_{3}$, in introducing a measure into the House of Commons to make further provision with respect to education in England and Wales, he made a notable speech in which he outlined his proposals, surveying the entire field of education up to that of the university. Realising the necessity for recruiting the elementary schools with a race of healthy children, he has put forth proposals enabling local authorities to establish nursery schools for children from two to five years of age in which the main regard shall be the health, the nourishment, and the physical welfare of the child. It may be urged with some force that the provision of such schools should be obligatory on the local authorities wherever the circumstances demand it.

Having regard to the enormous national expenditure upon elementary education, and the necessity for conserving its full fruit, the Bill proposes to raise the compulsory full-time school age, without any remissions, to fourteen, and in order to prevent the waste of educational opportunity that now ensues on leaving the elementary school, to provide for further continued education, within the normal working hours, extending to at least eight hours per week for forty weeks in each year-in all, a period of 320 hours-embracing a course of instruction general and special, including physical training, and having regard to their future as parents and citizens as well as to their chosen vocation, for all young people from fourteen years until the age of eighteen is reached. This means the abolition of half-time for children under fourteen years of age, which prevails mainly (it exists scarcely anywhere else) in the textile towns of East Lancashire and the West Riding of Yorkshire. No measure is more fraught with potential good than these comprising the extension of the full-time school age until fourteen and the provision of the means of continued education of adolescents until the age of eighteen. The acceptance of this policy will simply revolutionise English education and raise up a race of young people ready for higher forms of instruction (provision is made for extending the sphere of the elementary school for children up to sixteen years of age) in relation to the wiser and more fruitful use of leisure, the possibility of a humaner life, and the claims of science in respect of all human activities, social and economic.

To give effect to these purposes will entail a vast expenditure in the way of suitable buildings, special equipment, and the provision of specially trained teachers, but the results will more than 
justify it. The claims of industry, narrowly viewed, must give way to the supreme claim that every child born to the nation is entitled to the fullest opportunities of development of which his natural powers are capable. There will be a strong opposition in certain industrial areas to these measures, but it is to be hoped that Mr. Fisher will receive the fullest possible support from all who seek the lasting well-being of the nation.

Among other proposals in the Bill is one providing for the establishment of provincial associations under the direct initiative and control of the Board of Education. Whilst it is very desirable that such associations should be formed, having regard to the common interests of areas larger in extent than those of individual education authorities, it should surely be regarded as more consonant with the free spirit of English institutions to have encouraged the voluntary alliance of neighbouring authorities rather than the erection of a bureaucratic organisation centred in the Board of Education in London. It is to be hoped that before proceeding to a second reading this and other sections of the Bill which tend to strengthen the central body at the expense of the local authorities will receive serious consideration. Mr. Fisher has shown commendable enterprise and wisdom in his provincial campaign. He has come face to face with various interests; he has been well received and has created a favourable impression, whilst there has been no lack of determined and wellinformed criticism of some important sections of his measure. Doubtless he will have profited much by his intimate contact with men and women of all ranks of life, educational and industrial, and the cause of education will have unquestionably gained much thereby.

\section{HEALTH AND THE STATE.}

Health and the State. By Dr. W. A. Brend. Pp. $\mathrm{xi}+354$. (London: Constable and Co., Ltd., 19r7.) Price ros. $6 d$. net.

THE main object of this book is to establish 1 the case for putting our public health affairs in the hands of those who have real knowledge of the subject," and "to demonstrate the need for complete re-organisation of the public health services." It is not necessary to read the whole of the eleven chapters which compose the volume to be fairly convinced that some re-organisation is indeed needed. Perhaps the chapter entitled "The Complexity of Public Health Administration" is sufficient by itself to achieve the author's aim.

Dr. Brend maintains that while there exists a very large mass of scientific knowledge at our NO. 25OI, VOL. IOO] disposal, the channels by which it reaches those who might be expected to benefit thereby are imperfect and obstructed. No fewer than eleven Government offices, five central authorities, and six local authorities are concerned to a greater or less extent in public health administration. Knowledge that has run the gauntlet of the Government offices and then weathered the storm of vested interests in the country at large is finally turned into law by a House in which it receives little or no expert scientific criticism. The seventh chapter-more than one-fifth of the book-is devoted to the Insurance Act, and is a remarkable exposition of the discrepancy that exists between knowledge and its application. The proposals and promises of I9I I are compared with the working of the Act to-day; the waste of opportunity for collecting valuable information, and the failure of the Act to apply the best medical treatment to the sick poor who are in need of it, are discussed at length.

Yet withal, the general impression left by the book is that though it is a careful study of present administration and a vigorous piece of destructive criticism, nevertheless the reconstructive proposals outlined are by no means necessarily sound. The author frequently postulates that environment lies at the root of nearly all the ills that flesh is heir to. He maintains that the number of unfit in a State depends more upon environment than upon any other factor, and that the main cause of the continuance of tuberculosis is a bad environment. "Defectiveness in school children, as most diseases elsewhere, is mainly a matter of environment." "Take a patch of, say, fifty acres from the most crowded and worst built district . . . set it down precisely as it is among the pines of Surrey ... the probability is that the improvement in the health of the inhabitants would be enormous. There are, in fact, patches of bad housing in many country towns and villages presenting the worst features of slums, whose inhabitants, nevertheless, exhibit a high degree of healthiness."

The chief factor at work in bad environment (i.e. overcrowding of cities) is, in Dr. Brend's view, an atmosphere polluted by dust and smoke. That polluted air may be harmful, as is polluted water, is not questioned, but the argument contained in the passage cited, that bad housing and slum conditions are in themselves comparatively unimportant, does not appear valid. It is a matter of experience that so long as communities are small and scattered human beings can live under the most primitive conditions without suffering unduly, but even picked individuals when aggregated in large numbers suffer heavily from preventable disease unless the most strict precautions are taken. It is not recorded that the armies of the Napoleonic wars were particularly subjected to dusty, smoke-polluted atmosphere, yet thëir sickness rate was terribly high. We question whether the fifty crowded acres in Surrey would necessarily prove to be particularly healthy, although; of course, it is not proposed 